JOURNAL OF SECURITY AND SUSTAINABILITY ISSUES

ISSN 2029-7017 print/ISSN 2029-7025 online

2019 June Volume 8 Number 4

http://doi.org/10.9770/jssi.2019.8.4(22)

Scopus ${ }^{\circ}$

\title{
FOOD SECURITY AND THE TRADE VIA LENSES OF SANCTIONS ${ }^{1}$
}

\author{
Mikhail Krivko ${ }^{1}$, Luboš Smutka ${ }^{2}$, Wadim Strielkowski ${ }^{3}$ \\ ${ }^{1}$ Department of Economics, Czech University of Life Sciences, Kamýcká 129, 16521 Prague, Czech Republic \\ ${ }^{2,3}$ Department of Trade and Finance, Czech University of Life Sciences, Kamýcká 129, 16521 Prague, Czech Republic
}

E-mails: ${ }^{1} k r i v k o @ p e f . c z u . c z,{ }^{2}$ smutka@pef.czu.cz; ${ }^{3}$ strielkowski@pef.czu.cz

Received 12 December 2018; accepted 22 April 2019; published 30 June 2019

\begin{abstract}
Our paper focuses on the issues of food security and agricultural trade. Specifically, we tackle the issue of economic selfsufficiency of a country using an example of the import ban on agricultural production as one form of economic sanctions. Our paper attempts to estimate the impact of sanctions in separate regions, rather then on the aggregate country level. We propose an original methodology of estimating allocation of import ban effects based on the OECD Customer Support Estimate (CSE). Our results demonstrate that in case of some agricultural products (e.g. potatoes) consumers in most of Russian regions were net beneficiaries before 2014, but the magnitude of the benefits decreased significantly after the introduction of sanctions. This provided Russian agricultural producers with more support arising from the market price differential. All in all, we find no significant evidence of the import ban impact, however after 2014 the cumulative cost paid by consumers in different regions declined significantly due to other factors, leaving consumers in the position of net beneficiaries. Our results demonstrate that despite the economic sanctions are important, they do not affect food security of neither of conflicting parties.
\end{abstract}

Keywords: food security; agricultural trade; economic development; agricultural market; economic sanctions; European Union

Reference to this paper should be made as follows: Krivko, M., Smutka, L., Strielkowski, W. (2019). Food security and tade via lenses of sanctions, Journal of Security and Sustainability Issues 8(4): 815-826. http://doi.org/10.9770/jssi.2019.8.4(22)

JEL Classifications: C10, F10, Q17

Additional disciplines political sciences; sociology; cultural studies; international relations

\section{Introduction}

Food security and agricultural trade constitute two very important issues in the security and sustainable development of any country. Nowadays, due to the vast development of international trade, any country in the world is hardly to become completely self-sufficient in the face of the economic sanctions on food and agricultural products (Tireuov et al., 2018; Akhmetova and Suleimenova, 2018; Vorotnikov et al., 2019; Bohdaniuk et al., 2019). Economic sanctions are often applied as tool of foreign policy. The result, as expected, is hampering of international trade and hardening the conditions for international economic exchange (Balitskiy et al., 2014; Brodzicki 2016; Cieślik et al. 2016; Niño-Amézquita et al. 2017; Tvaronavičienè, 2018).

In 2014, the United States (U.S.) and the European Union (EU) applied restrictive measures that included target economic sanctions against Russian Federation. As an answer to Western sanctsions, in August 2014, Russia replied with countersanctions and introduced an import ban (the so-called "Russian embargo") on the several

1 Article is prepared with support from Internal Grant Agency of Faculty of Economics and Management, Czech University of Life Sciences, project 20181017 - Influence of economic sanctions and embargo on agricultural sector in Russian Federation and European Union. 
European agricultural products, including meat, fish, cheese, milk, fresh fish, vegetables, and fruits. Russian import ban referred to all the goods originated from the United States, EU Member States, Norway, Canada, and Australia (Vorotnikov et al. 2019).

In March 2014, the European Council approved the first diplomatic action in response to Russian agression in Ukraine: economic sanctions were imposed in July 2014 and strengthened them in September 2014.

Trade relations between Russia and the EU were already volatile prior to sanctions due to the Russian economy showing signs of weakness.

Russian import ban was introduced by the Russian government in 2014 and included meat, fish, cheese, milk, fresh fish, vegetables and fruits produced in the EU, the USA, Norway, Australia and Iceland. Import ban was a reaction on European sanctions, imposed by EU on Russian Federation.

Import ban might lead one to be curious on whether the import ban has helped to achieve food security and self-sufficiency in terms of products in the scope of the ban. In other words, the issue of calculating the cost of achieving self-sufficiency and food security arises.

This paper takes a look at the Consumer Support Estimate (or CSE) as one of the indicators that characterizes the amount of transfers to consumers of agricultural products as a result of the policies adopted in the country of interest. CSE was developed by OECD along with other indicators, such as Producers Support Estimate (or PSE), General Services Support Estimate (GSSE) and Total Support Estimate (TSE) in order to evaluate the amount and direction of support to producers and consumers of agricultural commodities. (OECD, 2016). We employ a methodology in which CSE is calculated for a specific commodity on country level. This approach gives us an overview of a transfers in a country on macro level, while it does not capture the differences between separate regions. It can be a significant restraint for the countries with heterogenous regional structure of economic development. The paper stimates the differences in CSE between different regions (or federal districts) of Russian Federation in order to capture the influence of import ban introduced by Russian Federation for specified commodities on transfers to/from consumers.

\section{Literature review}

With relation to the general topic of sanctions impact on economy, several works exist. Hufbauer et al. (1997) studied the impact of U.S. economic sanctions and its impact on trade, jobs, and wages. Authors applied gravity model to the cross-sectional data set for the years of 1985, 1990 and 1995 to find the effect of US sanctions on bilateral merchandise trade flows (export plus import). The results showed a large impact of sanctions on trade flows, which caused reduction of around 90 percent. Later Hufbauer and Oegg (2003) attempted to apply Andrew Rose's gravity model, which includes 14 control variables, to assess the impact of economic sanctions on U.S. trade. As authors attempted to estimate the effect of limited, moderate and extensive sanctions, it was found that limited and moderate sanctions had little or no effect on trade flows, while extensive sanctions had a large depressing effect on bilateral trade, decreasing trade flows between U.S. and countries by 95 to 99 percent. With regard to that, Kaempfer and Lowenberg (2007) state that an import ban always leads to redistributional impact on both sanctioning and targeted country.

Another interesting piece of research focuses on short-run and long-run effects of sanctions on foreign direct investment (FDI) (Mirkina, 2018). The author tests the effect of sanction imposition on foreign investment on the larger set of data for 184 countries from 1970 to 2010 using bias-corrected estimator introduced by Pesaran (Pesaran, 2006), that addresses common methodological issues of sanctions' studies, such as highly-trending or non-stationary variables, cross-sectionally correlated errors of panel regressions, and parameters' heterogeneity. The results show, that sanctions seem to have effect on FDI, but when all sanctions are considered together or when extensive and limited sanctions are separated this effect is not statistically significant. High-cost sanctions have a significant negative effect in the short run. However, this effect disappears in the long run, low-cost 
sanctions do not show statistically significant impact (Mirkina, 2018).

The US sanctions seem to have substantial and significant negative effect on FDI in the long run. The author points out two possible explanations. The first is that in case of unilateral US sanctions investors might be slower in making disinvestment decisions than in case of international, i.e. initiated by United Nations, sanctions. In this case the adjustment of the economy to the new equilibrium may be delayed. The second explanation reverts to the reasoning of the sanctions: the country with higher US FDI is less likely to be sanctioned by US, but once sanctions are imposed the declining US FDI will contribute to the success of the sanctions. However, the author leaves further testing of these two hypotheses for future research (Mirkina, 2018).

Current academic discussion on the whole topic of EU-Russia trade goes in two parallel directions: about the economic effects of EU sanctions and about the economic effect of Russian embargo. Within the discussion on economic effects of EU sanctions on Russia some of the researchers conclude that there is an evidence for sanctions impact, but they cannot be considered as a leading factor for Russian economy development for the given period. Gurvich and Prilepskiy (2015) estimated the sanctions impact at the level of minus 2.4 percent of GDP by the year 2017, but this impact is 3.3 times lower than the impact of oil prices shock.

The possible economic effect on US, EU and Russian Federation was assessed in (Dong and Li, 2018), using numerical general equilibrium model and economic sanction game methodology. The findings of the authors show, that all sanction involved countries will be hurt, but comparatively Russia will be hurt more, than U.S. and EU. According to the scenarios suggested by authors, in case of soft sanctions Russian GDP would decline by $1.45 \%$, hard sanctions $-4.35 \%$, and forbidden sanctions by $8.86 \%$.

Regarding the effect of Russian embargo on agricultural sector, in the very beginning of the story the Policy department of European Parliament estimated that Russian import ban will affect $73 \%$ of EU import to Russia (Kraatz, 2014). Nevertheless, some of the researchers come the conclusion that the effect in EU economies could be too small (Androniceanu \& Popescu, C.R., 2017). After reviewing data on agricultural trade between EU countries, (Dreve et al., 2015) conclude that even if the loss of the Russian market will cause job losses, the effect on labor market would be too small to be reflected in national statistics, as the share of agriculture in GDP is low in most countries. At the same time, (Kutlina-Dimitrova, 2017) after modelling simulation using computable general equilibrium model (also known as CGE model) shows, that the impact of the ban on total exports of the EU, the USA, Norway, Canada and Australia is limited, nevertheless at a disaggregate level there are sectors - 'vegetables and fruits', 'other meat' and 'dairy products' - which experience two-digit percentage change declines.

Smutka et al. (2016) analysed how Russian embargo affected the structure of Russian agri-food imports and show, that the most affected product groups were perishable vegetables and fruits. At the same time, authors show that embargo resulted in decreased competition on the domestic market, and in combination with other factors (Androniceanu, 2017a; Androniceanu, 2017b), such as rouble depreciation and increase of transaction costs, led to rapid growth of food prices, from $2.66 \%$ in 2013 to $14.1 \%$ in 2014 .

Regarding domestic effects of import ban, some authors point out that the results vary across sub-sectors, with increases in production of pork and decreases among dairy, beef and fish producers (Wengle, 2016). At the same time, there is an evidence that Russia has become more self-sufficient in food and seafood. Western trading partners for food and seafood have been replaced by partners from Asia and Central Asia (Wegren and Elvestad, 2018).

The effects on consumer's demand are examined in (Berendeeva and Ratnikova, 2018). The authors attempted to assess the changes in price and income elasticity of demand for foodstuff products before and after Russian import ban imposition using QUAIDS model based on the data of Russian Longitudinal Economic Survey (2010-2016) for two types of households: urban households and landowners. The results of the modelling show increase in price elasticity of demand for almost all product categories, except meat and meat products, for both groups of households. Meat and meat products' price elasticity of demand for landowners significantly decreased, showing 
low sensitivity of demand to changes in price and high dependence of Russian landowners' households on meat products. These finding complements to the previous survey (Staudigel and Schrock, 2015), showing that meat accounts up to $28 \%$ of household's food budget, representing the biggest category of food expenditures.

One of the very important additions to the discussion is the concept of food security and self-sufficiency. Wegren et al. (2017) point out, that Russia's political leaders have a different understanding of food security than traditional usage. From their perspective, Russian variant of food security connects food trade to national security, making Russia food insecure based on food imports. Thus, it is crucial to achieve self-sufficiency in terms of foodstuff products, because otherwise the country is vulnerable. With regard to the above, it appears that from its introduction back in 2010, the Russian food security policy resulted in improvements of average per capita food consumption, although the poor consume much less (Wegren et al., 2016). This fact brings one to the important question: who paid the cost of self-sufficiency, and what is the value of this cost?

\section{Methodology}

The data for the research comes from OECD (2016) database (CSE, producer prices, production volumes) and Federal State Statistics Service of Russian Federation (Rosstat 2019) (federal and regional producer prices, federal and regional production volumes). Data covers period from 2010 to 2016. Time period of the data used is chosen based on the availability of the most recent data. Our research questions are formulated as follows:

1. How country Consumer Support Estimate can be separated into Consumer Support Estimates for regions of the country (federal districts of Russia)?

2. How can the impact of differences in production and prices of a single commodity among regions be estimated?

3. How can the Consumer Support Estimate be allocated to each producer inside the specified region?

4. What evidence of Russian import ban impact can be found in changes of Consumer Support Estimate after 2014 ?

Consumer Support Estimate is calculated according to OECD methodology (see OECD, 2016):

$$
C S E_{c}=T C T_{c}-\left(T P C_{c}+O T C_{c}\right)+E F C_{c}
$$

where: $C S E_{c}$ - consumer support estimate for commodity $c$ in local currency; $T C T_{c}$ - value of transfers to consumers from taxpayers for commodity $c$ in local currency; $T P C_{c}$ - transfers to producers from consumers for commodity $c$ in local currency; $O T C_{c}$ - other transfers to consumers of commodity $c$ in local currency; $E F C_{c}$ exceed feed cost for commodity $c$ in local currency.

Single Commodity Transfer (SCT) shows the transfers to producers that relate only to specific commodity. In case of imported commodity, it is calculated as follows:

$$
\text { consumer } S C T_{c}=T C T_{c}-Q P_{c} *\left(P P_{c}-R P_{c}\right)-O T C_{c}+E F C_{c}
$$

where consumer $S C T_{c}$ - single commodity transfer to consumers of commodity $c$ (hereafter SCT);

For the purposes of SCT calculation for Russian Federation, OECD uses several different prices as $B P_{c}$ in order to arrive to $R P_{c}$, or reference price. The examples for the commodities that are in the import ban list can be seen on the Table 1.

Moreover, OECD calculates the indicators of support for a range of commodities that accounts for the largest part of countries import and export. The list of commodities is specified for each country and is included in Table 1 that follows. Several commodities from the list has been under the import ban from 2014 including the beef and veal, milk, poultry, potatoes, and pork. 
Table 1. Types of prices used as border price for commodities included in import ban list, according to OECD methodology.

\begin{tabular}{|l|c|c|c|c|}
\hline Commodity & $\begin{array}{c}\text { Commodity } \\
\text { sign }\end{array}$ & $\begin{array}{c}\text { Russia's position in trade } \\
\text { for the commodity }\end{array}$ & Price used as border price & Type of price used \\
\hline Beef and veal & BF & Net importer & Import price (CIF) & Traded price, Country's own prices \\
\hline Milk & MK & Net importer & Import price (CIF) & Traded price, Country's own prices \\
\hline Poultry & PT & Net importer & Import price (CIF) & Traded price, Country's own prices \\
\hline Potatoes & PO & Net importer & Import price (CIF) & Traded price, Country's own prices \\
\hline Pigmeat & PK & Net importer & Export price (FOB) & Traded price, other country \\
\hline
\end{tabular}

Source: OECD

Estimations for single commodity transfer are made on aggregate level for the whole economy of the country. It does not account for differences between regions. It is especially the case for Russian Federation, as it consists of more than 80 regions, grouped in federal districts, and the regions and federal districts vary significantly in commodity prices, agricultural production and consumption. It is possible to calculate corresponding coefficients that will break down country's SCT to recalculate it into SCT for separate federal districts.

In case of potatoes, OECD estimates $T C T_{c^{\prime}} O T C_{c}$ and $E F C_{c}$ are equal to zero. In this relation, share of specific region $j$ in country's $\mathrm{SCT}$ for potatoes can be expressed as:

$$
S C T_{c j}=\left(\alpha_{1 c j} * Q P_{c} * \alpha_{2 c j} * P P_{c}-\alpha_{1 c j} * Q P_{c} * \alpha_{3 c j} * R P_{c}\right)
$$

where $\alpha_{I c j}-\quad$ regional coefficient for $Q P_{c}$;

$\alpha_{2 c j}-$ regional coefficient for $P P_{c}$;

$\alpha_{3 c j}-$ regional coefficient for $R P_{c}^{c}$.

SCT in different regions can be calculated according to the differences in productions quantities, producer's prices and reference prices (assuming both $P P$ and $R P$ are constants among regions). There are no differences in quality between imported and domestically produced products, and no weight adjustment made, reference price is equal:

$$
R P_{c}=B P_{c}
$$

As prices used in calculation are adjusted to the farm gate level, the costs of transportation of imported product to country's wholesale market increase reference price, while costs of transportation of domestically produced products to the wholesale market decrease reference price. Due to the fact that reliable data on transportation costs in both directions are difficult to obtain, these costs can be omitted in majority of cases as per OECD methodology.

Allocation of SCT to a specified producer inside a region becomes complicated due to the fact, that not all produced volume of commodity is consumed inside the region, and not all consumed volume of commodity is produced inside the region. At the same time, allocation to a producer might be done on the basis of fertile land. For higher precision, fertile land of a specific commodity might be used for calculations.

Allocation of SCT to a producer on per hectare of fertile land helps to capture differences in production capacity of the region, rather than consumption volumes. This type of allocation can also be very helpful to attribute the region's SCT to farm size category (small farms, medium farms, vertically integrated agricultural holdings etc), as well as to attribute the region's SCT to each individual farm, as this information is normally easy to obtain from statistical databases. It is important to mention, that SCT per hectare should be considered with opposite sign in comparison to SCT. This is done due to the fact, that SCT shows transfers from consumer's point of view, while SCT per hectare makes more sense from producer's perspective. 


\section{Results and discussions}

Consumer SCT for potatoes for different Russian federal districts are shown in the Table 2. Values for Russian Federation are calculated as a sum of values for all regions. For Russian Federation in general, in year 2010 single commodity transfer to producers was equal to $202,837 \mathrm{mln}$ rubles, while it dropped to negative $22,840 \mathrm{mln}$ rubles in the next year of 2011. The changes in SCT are mainly due to significant increase in potatoes production that entailed producers' price decrease, whilst reference price, i.e. border price, did not show significant changes (see Table 3). During the period of 2012-2016 there was no visible trend, as SCT showed significant differences between consecutive years. Regions of Russia did not show a trend in SCT as well. All of them had higher values in 2010 and 2012, while negative values in 2014 and (except Siberian Federal District) in 2015.

Table 2. Commodity SCT for potatoes for years 2010-2016, in millions of rubles

\begin{tabular}{|c|c|c|c|c|c|c|c|c|}
\hline \multirow{2}{*}{$\begin{array}{c}\text { Federal } \\
\text { District }\end{array}$} & \multirow{2}{*}{ Indicator } & \multicolumn{5}{|c|}{ Potatoes } \\
\cline { 5 - 9 } & $\mathbf{2 0 1 0}$ & $\mathbf{2 0 1 1}$ & $\mathbf{2 0 1 2}$ & $\mathbf{2 0 1 3}$ & $\mathbf{2 0 1 4}$ & $\mathbf{2 0 1 5}$ & $\mathbf{2 0 1 6}$ \\
\hline Russian Federation & $\mathrm{SCT}_{\mathrm{c}}$ & $202,837.33$ & $-22,840.54$ & $313,036.23$ & $28,993.18$ & $-54,289.38$ & $-75,289.20$ & $227,714.99$ \\
\hline $\begin{array}{c}\text { Central Federal } \\
\text { District }\end{array}$ & $\mathrm{SCT}_{\mathrm{cl}}$ & $47,820.42$ & 503.73 & $111,611.16$ & $21,800.46$ & $-13,060.73$ & $-5,375.01$ & $80,032.31$ \\
\hline $\begin{array}{c}\text { North-Western } \\
\text { Federal District }\end{array}$ & $\mathrm{SCT}_{\mathrm{c} 2}$ & $13,378.32$ & -916.75 & $15,544.80$ & 908.85 & $-5,439.73$ & $-11,376.83$ & $7,733.50$ \\
\hline $\begin{array}{c}\text { Southern Federal } \\
\text { District }\end{array}$ & $\mathrm{SCT}_{\mathrm{c} 3}$ & $11,749.92$ & $-8,631.24$ & $8,473.67$ & $-3,613.28$ & $-7,112.91$ & $-7,799.62$ & $12,912.05$ \\
\hline $\begin{array}{c}\text { North-Caucasian } \\
\text { Federal District }\end{array}$ & $\mathrm{SCT}_{\mathrm{c} 4}$ & $9,885.73$ & $-5,334.91$ & $11,490.42$ & $-1,602.28$ & $-5,994.43$ & $-7,378.36$ & $5,218.92$ \\
\hline $\begin{array}{c}\text { Volga Federal } \\
\text { District }\end{array}$ & $\mathrm{SCT}_{\mathrm{c} 5}$ & $32,380.71$ & $-12,438.76$ & $87,828.16$ & $11,527.73$ & $-4,747.37$ & $-23,848.34$ & $62,597.25$ \\
\hline $\begin{array}{c}\text { Ural Federal } \\
\text { District }\end{array}$ & $\mathrm{SCT}_{\mathrm{c} 6}$ & $20,057.35$ & $-4,088.68$ & $23,410.60$ & $6,439.61$ & $-2,162.26$ & $-3,629.58$ & $13,330.51$ \\
\hline $\begin{array}{c}\text { Siberian Federal } \\
\text { District }\end{array}$ & $\mathrm{SCT}_{\mathrm{c} 7}$ & $58,947.54$ & $18,533.03$ & $49,378.84$ & 946.57 & $-2,187.70$ & $1,951.40$ & $48,788.77$ \\
\hline $\begin{array}{c}\text { Far Eastern Federal } \\
\text { District }\end{array}$ & $\mathrm{SCT}_{\mathrm{c} 8}$ & $8,617.33$ & $-10,466.96$ & $5,298.58$ & $-7,414.47$ & $-13,584.25$ & $-17,832.87$ & $-2,898.33$ \\
\hline
\end{tabular}

Source: own calculations

Production volumes, producers' prices and reference prices in regions of Russia had the same dynamics as in Russian Federation in general.

Table 3. Production volume, producers' price and reference price for potatoes, Russian Federation.

\begin{tabular}{|l|c|c|c|c|c|c|c|}
\hline & $\mathbf{2 0 1 0}$ & $\mathbf{2 0 1 1}$ & $\mathbf{2 0 1 2}$ & $\mathbf{2 0 1 3}$ & $\mathbf{2 0 1 4}$ & $\mathbf{2 0 1 5}$ & $\mathbf{2 0 1 6}$ \\
\hline Production volume, 1000 tons & 21140.50 & 32681.30 & 29532.40 & 30184.40 & 31501.50 & 33645.90 & 31107.80 \\
\hline Producers' price, rub/ton & 19503.73 & 8470.63 & 9571.62 & 12451.11 & 14550.22 & 12680.47 & 14461.31 \\
\hline Reference price, rub/ton & 16124.36 & 18653.68 & 18193.75 & 10149.47 & 11787.73 & 14429.24 & 16425.30 \\
\hline
\end{tabular}

Source: Rosstat, OECD.

Comparison of averages gives another insight into the movement in SCT in regions of Russia. As seen on the Table 4, average SCT during the period of 2002-2013, before Russian import ban, was positive in all regions except two, Southern and Far Eastern Federal Districts. Values of 3-year average before Russian import ban (2011-2013) had the same sign as in 2002-2013 but are higher in value for each of the regions. Comparison of 3-year average before and after import ban (2014-2016) reveals decrease for all regions, except Southern Federal District which showed $46.95 \%$ increase in transfers from producers to consumers. At the same time, in case of Southern Federal District the 3-year average values changed from negative 1,256.95 mln rubles to negative $666.83 \mathrm{mln}$ rubles, which is the lowest absolute changes in 3-year average after 2013 across all Russian regions. All other regions experienced significant decrease in 3-year average. This fact constitutes, that transfers from producers to consumers decreased in the period after Russian import ban for the majority of 
Russian regions. For majority of Russian regions, consumers were net receivers of transfers during the whole period of 2002-2016, but after Russian import ban the value of this net benefit decreased significantly.

While there is an evidence that Russian consumers benefited after 2013, the magnitude of how much consumers benefited in one region in comparison to other was significantly different for different regions. At the same time, it is important to understand what the drivers of this benefit were. Methodology proposed in this paper helps to estimate in percentage terms the differences in SCT between regions, taking into consideration how far each region's SCT is from expected value, calculated using median values.

Table 4. Changes in averages for commodity SCT for potatoes for years 2010-2016, in millions of rubles

\begin{tabular}{|l|c|c|c|c|c|}
\hline & $\begin{array}{c}2002-2013 \\
\text { average }\end{array}$ & $\begin{array}{c}2011-2013 \\
\text { average }\end{array}$ & $\begin{array}{c}2014-2016 \\
\text { average }\end{array}$ & $\begin{array}{c}\text { Absolute change } \\
\text { of average after } \\
2013\end{array}$ & $\begin{array}{c}\% \text { change of } \\
\text { average after } \\
2013\end{array}$ \\
\hline Central Federal District & $21,013.60$ & $44,638.45$ & $20,532.19$ & $-24,106.26$ & $-54.00 \%$ \\
\hline North-Western Federal District & $2,706.57$ & $5,178.97$ & $-3,027.69$ & $-8,206.65$ & $-158.46 \%$ \\
\hline Southern Federal District & $-2,439.53$ & $-1,256.95$ & -666.83 & 590.13 & $46.95 \%$ \\
\hline North-Caucasian Federal District & $1,203.25$ & $1,517.74$ & $-2,717.96$ & $-4,235.70$ & $-279.08 \%$ \\
\hline Volga Federal District & $15,729.43$ & $28,972.38$ & $11,333.85$ & $-17,638.53$ & $-60.88 \%$ \\
\hline Ural Federal District & $5,266.66$ & $8,587.18$ & $2,512.89$ & $-6,074.28$ & $-70.74 \%$ \\
\hline Siberian Federal District & $15,032.02$ & $22,952.81$ & $16,184.16$ & $-6,768.66$ & $-29.49 \%$ \\
\hline Far Eastern Federal District & -923.45 & $-4,194.28$ & $-11,438.48$ & $-7,244.20$ & $-172.72 \%$ \\
\hline
\end{tabular}

Source: own calculations

Components of regional SCT shows the production and price elasticity of SCT.

Table 5. Components of regional SCT after applying Taylor series approach for years 2010-2016, in millions of rubles

\begin{tabular}{|c|c|c|c|c|c|c|c|}
\hline & $\mathbf{2 0 1 0}$ & $\mathbf{2 0 1 1}$ & $\mathbf{2 0 1 2}$ & $\mathbf{2 0 1 3}$ & $\mathbf{2 0 1 4}$ & $\mathbf{2 0 1 5}$ & $\mathbf{2 0 1 6}$ \\
\hline \multicolumn{1}{|c|}{$S C T_{c j}\left(M_{1} ; M_{2}\right)$} & $15,025.15$ & $-3,303.77$ & $20,418.95$ & 844.97 & $-5,643.50$ & $-7,748.33$ & $13,159.60$ \\
\hline Production elasticity of SCT & $195,362.09$ & $-46,866.76$ & $316,829.05$ & $12,447.13$ & $-81,083.12$ & $-119,193.23$ & $181,948.56$ \\
\hline Price elasticity of SCT & $-15,448.29$ & $-23,746.86$ & $-14,544.94$ & $-19,357.31$ & $-28,279.51$ & $-28,864.48$ & $-23,056.98$ \\
\hline
\end{tabular}

Source: own calculations

Impacts of differences in production and differences in prices that are shown on Table 6 and Table 7, provide an evidence, that the main driver of the differences in SCT among Russian regions is difference in production. Except Far Eastern Federal District, all of the regions showed dependence on production coefficient, because production coefficient describes more than $50 \%$ of difference in SCT in at least 4 cases out of 7 . For Far Eastern Federal District, price coefficient describes more than 50\% of difference for the whole period of 2010-2016.

Table 6. Impacts of production coefficient $\alpha_{1 c j}$ on regional SCT after applying Taylor series approach for years 2010-2016, in \%.

\begin{tabular}{|l|c|c|c|c|c|c|c|}
\hline & $\mathbf{2 0 1 0}$ & $\mathbf{2 0 1 1}$ & $\mathbf{2 0 1 2}$ & $\mathbf{2 0 1 3}$ & $\mathbf{2 0 1 4}$ & $\mathbf{2 0 1 5}$ & $\mathbf{2 0 1 6}$ \\
\hline Central Federal District & $100.00 \%$ & $148.54 \%$ & $97.72 \%$ & $66.23 \%$ & $113.70 \%$ & $125.96 \%$ & $89.03 \%$ \\
\hline North-Western Federal District & $299.76 \%$ & $35.70 \%$ & $88.69 \%$ & $-123.48 \%$ & $-277.69 \%$ & $-36.76 \%$ & $82.32 \%$ \\
\hline Southern Federal District & $72.70 \%$ & $-12.08 \%$ & $15.28 \%$ & $2.96 \%$ & $-52.14 \%$ & $-418.77 \%$ & $393.04 \%$ \\
\hline North-Caucasian Federal District & $73.27 \%$ & $-30.84 \%$ & $51.93 \%$ & $7.85 \%$ & $-116.27 \%$ & $-374.64 \%$ & $45.64 \%$ \\
\hline Volga Federal District & $100.00 \%$ & $98.55 \%$ & $98.04 \%$ & $50.85 \%$ & $142.76 \%$ & $107.48 \%$ & $84.57 \%$ \\
\hline Ural Federal District & $53.40 \%$ & $115.56 \%$ & $68.52 \%$ & $3.43 \%$ & $-39.36 \%$ & $-36.45 \%$ & $393.04 \%$ \\
\hline Siberian Federal District & $93.52 \%$ & $-91.83 \%$ & $98.00 \%$ & $155.12 \%$ & $242.33 \%$ & $433.63 \%$ & $71.08 \%$ \\
\hline Far Eastern Federal District & $43.19 \%$ & $-10.43 \%$ & $32.94 \%$ & $2.62 \%$ & $-15.34 \%$ & $-16.43 \%$ & $25.84 \%$ \\
\hline
\end{tabular}

Source: own calculations 
Table 7. Impacts of price coefficient $\alpha_{2 c j}$ on regional SCT after applying Taylor series approach for years 2010-2016, in \%.

\begin{tabular}{|l|c|c|c|c|c|c|c|}
\hline & $\mathbf{2 0 1 0}$ & $\mathbf{2 0 1 1}$ & $\mathbf{2 0 1 2}$ & $\mathbf{2 0 1 3}$ & $\mathbf{2 0 1 4}$ & $\mathbf{2 0 1 5}$ & $\mathbf{2 0 1 6}$ \\
\hline Central Federal District & $0.00 \%$ & $-48.54 \%$ & $2.28 \%$ & $33.77 \%$ & $-13.70 \%$ & $-25.96 \%$ & $10.97 \%$ \\
\hline North-Western Federal District & $-199.76 \%$ & $64.30 \%$ & $11.31 \%$ & $223.48 \%$ & $377.69 \%$ & $136.76 \%$ & $17.68 \%$ \\
\hline Southern Federal District & $27.30 \%$ & $112.08 \%$ & $84.72 \%$ & $97.04 \%$ & $152.14 \%$ & $518.77 \%$ & $-293.04 \%$ \\
\hline North-Caucasian Federal District & $26.73 \%$ & $130.84 \%$ & $48.07 \%$ & $92.15 \%$ & $216.27 \%$ & $474.64 \%$ & $54.36 \%$ \\
\hline Volga Federal District & $0.00 \%$ & $1.45 \%$ & $1.96 \%$ & $49.15 \%$ & $-42.76 \%$ & $-7.48 \%$ & $15.43 \%$ \\
\hline Ural Federal District & $46.60 \%$ & $-15.56 \%$ & $31.48 \%$ & $96.57 \%$ & $139.36 \%$ & $136.45 \%$ & $-293.04 \%$ \\
\hline Siberian Federal District & $6.48 \%$ & $191.83 \%$ & $2.00 \%$ & $-55.12 \%$ & $-142.33 \%$ & $-333.63 \%$ & $28.92 \%$ \\
\hline Far Eastern Federal District & $56.81 \%$ & $110.43 \%$ & $67.06 \%$ & $97.38 \%$ & $115.34 \%$ & $116.43 \%$ & $74.16 \%$ \\
\hline
\end{tabular}

Source: own calculations

Table 8. Fertile land used for potatoes for years 2010-2016, in hectares

\begin{tabular}{|l|c|c|c|c|c|c|c|}
\hline & $\mathbf{2 0 1 0}$ & $\mathbf{2 0 1 1}$ & $\mathbf{2 0 1 2}$ & $\mathbf{2 0 1 3}$ & $\mathbf{2 0 1 4}$ & $\mathbf{2 0 1 5}$ & $\mathbf{2 0 1 6}$ \\
\hline Central Federal District & $575,860.00$ & $568,060.00$ & $549,860.00$ & $507,670.00$ & $483,800.00$ & $475,140.00$ & $430,750.00$ \\
\hline North-Western Federal District & $90,640.00$ & $91,470.00$ & $88,420.00$ & $77,200.00$ & $73,470.00$ & $74,080.00$ & $71,760.00$ \\
\hline Southern Federal District & $143,800.00$ & $146,500.00$ & $148,500.00$ & $141,000.00$ & $139,300.00$ & $141,660.00$ & $84,520.00$ \\
\hline North-Caucasian Federal District & $86,530.00$ & $91,130.00$ & $93,090.00$ & $77,390.00$ & $76,280.00$ & $77,000.00$ & $70,050.00$ \\
\hline Volga Federal District & $534,570.00$ & $493,980.00$ & $476,480.00$ & $433,990.00$ & $402,640.00$ & $395,000.00$ & $363,470.00$ \\
\hline Ural Federal District & $145,790.00$ & $147,010.00$ & $149,380.00$ & $142,270.00$ & $134,790.00$ & $130,700.00$ & $124,830.00$ \\
\hline Siberian Federal District & $314,220.00$ & $305,570.00$ & $294,650.00$ & $276,190.00$ & $262,010.00$ & $250,950.00$ & $235,800.00$ \\
\hline Far Eastern Federal District & $81,850.00$ & $80,050.00$ & $77,220.00$ & $70,830.00$ & $66,310.00$ & $63,940.00$ & $60,090.00$ \\
\hline
\end{tabular}

Source: Rosstat (2019)

Change in the position of producers can be assessed by allocation of SCT in region to the hectare of fertile land used for potatoes. Table 8 shows the square of fertile land for potatoes for Russian regions, while Table 9 shows the SCT value per hectare.

After Russian import ban in 2014, all regions show either decrease in SCT per hectare or change in sign of transfer. Negative SCT per hectare means that producers are net receivers of transfers from consumers, and this situation is observed in almost all the regions in years 2014-2015.

Table 9. SCT for potatoes per hectare of fertile land for years 2010-2016, in thousands of rubles

\begin{tabular}{|l|c|c|c|c|c|c|c|}
\hline & $\mathbf{2 0 1 0}$ & $\mathbf{2 0 1 1}$ & $\mathbf{2 0 1 2}$ & $\mathbf{2 0 1 3}$ & $\mathbf{2 0 1 4}$ & $\mathbf{2 0 1 5}$ & $\mathbf{2 0 1 6}$ \\
\hline Central Federal District & $83,041.75$ & 886.75 & $202,981.04$ & $42,942.19$ & $-26,996.14$ & $-11,312.48$ & $185,797.59$ \\
\hline North-Western Federal District & $147,598.38$ & $-10,022.43$ & $175,806.41$ & $11,772.68$ & $-74,040.16$ & $-153,574.92$ & $107,768.99$ \\
\hline Southern Federal District & $81,710.13$ & $-58,916.33$ & $57,061.73$ & $-25,626.13$ & $-51,061.79$ & $-55,058.71$ & $152,769.14$ \\
\hline North-Caucasian Federal District & $114,246.31$ & $-58,541.73$ & $123,433.40$ & $-20,704.01$ & $-78,584.55$ & $-95,822.89$ & $74,502.84$ \\
\hline Volga Federal District & $60,573.37$ & $-25,180.70$ & $184,327.07$ & $26,562.19$ & $-11,790.62$ & $-60,375.54$ & $172,221.23$ \\
\hline Ural Federal District & $137,577.02$ & $-27,812.24$ & $156,718.45$ & $45,263.31$ & $-16,041.66$ & $-27,770.28$ & $106,789.33$ \\
\hline Siberian Federal District & $187,599.58$ & $60,650.68$ & $167,584.74$ & $3,427.24$ & $-8,349.69$ & $7,776.06$ & $206,907.43$ \\
\hline Far Eastern Federal District & $105,282.00$ & $-130,755.25$ & $68,616.67$ & $-104,679.85$ & $-204,859.70$ & $-278,900.06$ & $-48,233.14$ \\
\hline
\end{tabular}

Source: own calculations

Significant decline in SCT per hectare in 2014 can be an evidence of Russian import ban effect, as it was introduced in 2014, but it can be noticed that almost the same situation has happened in 2011 . The reason behind can be found in comparison of price coefficient impact from Table 7. In both 2011 and 2014-2015, the 
impact of price coefficient on the difference between regions was higher than $50 \%$ in majority of the regions. Generally speaking, higher impact of price coefficient is associated with higher transfers from consumers to producers. Producers benefit more from increase in price of potatoes, then from increase in production volumes.

It is important to mention, that production volume of potatoes in Russian Federation in 2010 and 2011 increased during one year from 21,140.50 mln tons to 32,681.30, and the producers' price dropped from 19,503.73 rubles per ton to $8,470.63$ rubles per ton. Reference price stayed on comparably stable level of $16,124.36$ rubles per ton in 2010 and 18,653.68 rubles per ton in 2011. Sharp increase in production caused drop in prices on domestic market, and this fact should have led consumers to become net receivers of transfers. On the country level this was true, but did not happen in each region, therefore transfers in separate regions show different picture, different from the transfers on the country level.

At the same time, SCT per hectare has remarkably grown in 2016, offsetting the impact of import ban. Cumulative amount of SCT per hactare for the years 2010-2016 are shown on the Table 10.

Table 10. Cumulative SCT for potatoes per hectare of fertile land for years 2010-2016, in thousands of rubles

\begin{tabular}{|l|c|c|c|c|c|c|c|}
\hline & $\mathbf{2 0 1 0 - 2 0 1 6}$ & $\mathbf{2 0 1 1 - 2 0 1 6}$ & $\mathbf{2 0 1 2 - 2 0 1 6}$ & $\mathbf{2 0 1 3 - 2 0 1 6}$ & $\mathbf{2 0 1 4 - 2 0 1 6}$ & $\mathbf{2 0 1 5 - 2 0 1 6}$ & $\mathbf{2 0 1 6}$ \\
\hline Central Federal District & $477,340.70$ & $394,298.94$ & $393,412.19$ & $190,431.15$ & $147,488.96$ & $174,485.11$ & $185,797.59$ \\
\hline North-Western Federal District & $205,308.95$ & $57,710.57$ & $67,733.00$ & $-108,073.41$ & $-119,846.08$ & $-45,805.92$ & $107,768.99$ \\
\hline Southern Federal District & $100,878.04$ & $19,167.91$ & $78,084.24$ & $21,022.51$ & $46,648.64$ & $97,710.43$ & $152,769.14$ \\
\hline North-Caucasian Federal District & $58,529.37$ & $-55,716.95$ & $2,824.79$ & $-120,608.61$ & $-99,904.61$ & $-21,320.05$ & $74,502.84$ \\
\hline Volga Federal District & $346,337.01$ & $285,763.64$ & $310,944.33$ & $126,617.26$ & $100,055.07$ & $111,845.69$ & $172,221.23$ \\
\hline Ural Federal District & $374,723.94$ & $237,146.91$ & $264,959.15$ & $108,240.70$ & $62,977.39$ & $79,019.05$ & $106,789.33$ \\
\hline Siberian Federal District & $625,596.04$ & $437,996.46$ & $377,345.78$ & $209,761.04$ & $206,333.80$ & $214,683.50$ & $206,907.43$ \\
\hline Far Eastern Federal District & $-593,529.33$ & $-698,811.33$ & $-568,056.08$ & $-636,672.76$ & $-531,992.91$ & $-327,133.20$ & $-48,233.14$ \\
\hline
\end{tabular}

Source: own calculations

Our results that are based on the cumulative data show that in almost all regions and in all years the SCT per hectare amounts were positive, meaning net transfers from producers to consumers. Only Far Eastern Federal district has shown negative SCT per hectare, which means that producers were in the position of net beneficiaries during all period.

\section{Conclusions}

Overall, one can see that the volume of agricultural products trade and the food security are influenced by sanctions and import bans. Although the reason of Western sanctions and embargo on Russia was political, the consequences of this decision reflected in the economies of both sides. Russian food security had experienced impact from Russian import ban after its introduction that entailed changes in domestic production volumes and led to increased self-sufficiency. However, the changes of food security in separate regions entailed by Russian import ban are not fully clear, as well as the cost of achieving food security by limiting agri-food import.

Main evidences from differences in CSE among Russian regions that stem from the current research, can be formulated as follows. During the years 2010-2011 the changes in SCT are mainly due to significant increase in potatoes production that entailed producers' price decrease, whilst reference price, i.e. border price, did not show significant changes. During the period of 2012-2016 there was no visible trend, as SCT showed significant differences between consecutive years. Regions of Russia did not show a trend in SCT as well. All of them had higher values in 2010 and 2012, while negative values in 2014 and (except Siberian Federal District) in 2015. Generally, potatoes market in Russian Federation has showed, that producers have incurred most of the cost of achieving food security and self-sufficiency. During the period of 2010-2016, consumers were in the position of net beneficiaries in all Russian regions except Far Eastern Federal District. At the same time, after Russian 
import ban in 2014 the value of this net benefit decreased significantly. The main driver of the differences in SCT among Russian regions is difference in production.

There is an evidence of negative SCT per hectare in almost all the regions in 2014-2015 which means, that producers are net receivers of transfers from consumers, but this effect disappears in 2016. While comparing period before and after import ban, the ban has not led to significant increase in transfers from consumers to producers. Our findings support the conclusion, that import ban had effect in 2014-2015 in some of the regions of Russian Federation, but this effect disappears already in 2016, meaning that import ban cannot be considered as a sustainable source of support for producers.

\section{Acknowledgements}

Article is prepared with support from Internal Grant Agency of Faculty of Economics and Management, Czech University of Life Sciences, project 20181017 - Influence of economic sanctions and embargo on agricultural sector in Russian Federation and European Union. The authors would like to thank Vladimir Lotereichik for the invaluable help with preparing mathematical model of production and price impacts on regional SCT.

\section{References}

Akhmetova, S. O., Suleimenova, M.S. (2018). Quality management system for improvement of quality and efficiency of food production: case of dairy products enterprise. Enterpreneurship and Sustainability Issues, 6(1), 289-310. http://doi.org/10.9770/jesi.2018.6.1(18)

Androniceanu, A. (2017a). Hospital management based on the relationship between doctors and patients. Administratie si Management Public, 29, 41-53.

Androniceanu, A., Popescu, CR. (2017). An inclusive model for an effective development of the renewable energies public sector, Administrație şi Management Public, 28, 81-96.

Androniceanu, A. (2017b). Improving citizens' satisfaction concerning the social welfare services at urban level. Theoretical and Empirical Researches in Urban Management, 12(4), 67-82.

Balitskiy, S., Bilan, Y., \& Strielkowski, W. (2014). Energy security and economic growth in the European Union. Journal of Security and Sustainability Issues, 4(2), 125-132.

Berendeeva, E., \& Ratnikova, T. (2018). Modeling the food embargo impact on the Russian households' consumption. HSE Economic Journal, 22(1), 9-39. https://doi.org/10.17323/1813-8691-2018-22-1-9-39

Bohdaniuk, O., Buriak, R., Savchuk, V. (2019). Competitiveness of horticultural products as a precondition of industry development. Entrepreneurship and Sustainability Issues, 6(4), 1587-1601. https://doi.org/10.9770/jesi.2019.6.4(3)

Brodzicki, T. (2016). Does variety matter? Export pattern of Poland prior and after the accession to the EU. International Economics Letters, 4(2), 103-118. https://doi.org/10.24984/iel.2016.4.2.5

Cieślik, A., Michałek, J., Mycielski, J. (2016). Globalization, international trade, and human development: a case of Central and Eastern Europe. Czech Journal of Social Sciences, Business and Economics, 5(2), 6-15. https://doi.org/10.24984/cjssbe.2016.5.2.1

Dong, Y., \& Li, C. (2018). Economic sanction game among the US, the EU and Russia: payoffs and potential effects. Economic Modelling, 73, 117-128 https://doi.org/10.1016/j.econmod.2018.03.006

Dreve, V., Calin, I., \& Bazga, B. (2015). Analysis of the Impact of Russian Embargo on the EU Agricultural and Food Sector. Scientific Papers: Series D, Animal Science-The International Session of Scientific Communications of the Faculty of Animal Science, 58. Available at: http://animalsciencejournal.usamv.ro/pdf/2015/Art64.pdf. Accessed 10 May 2019

Gurvich, E., \& Prilepskiy, I. (2015). The Impact of Financial Sanctions on the Russian Economy. Russian Journal of Economics, 1, 359-385. https://doi.org/10.1016/j.ruje.2016.02.002

Hufbauer, G.C., \& Oegg, B. (2003). The Impact of Economic Sanctions on US Trade: Andrew Rose's Gravity Model. Number PB03-4, April 2003, International Economics Policy Briefs, Institute for International Economics. 
Hufbauer, G.C., Elliott, K.A., Cyrus, T., \& Winston, E. (1997). US Economic Sanctions: Their Impact on Trade, Jobs, and Wages. Working Papers, Peterson Institute for International Economics.

Kaempfer W.H., \& Lowenberg A.D. (2007). The Theory of International Economic Sanctions: A Public Choice Approach. American Economic Review, 78, 786-793.

Kraatz, S. (2014). The Russian embargo: Impact on the economic and employment situation in the EU. European Parliament. Available at: http:/www.europarl.europa.eu/RegData/etudes/BRIE/2014/536291/IPOL_BRI(2014)536291_EN.pdf. Accessed 11 May 2019

Kutlina-Dimitrova, Z. (2017). The economic impact of the Russian import ban: a CGE analysis. International Economics and Economic Policy, 14(4), 537-552. https://doi.org/10.1007/s10368-017-0376-4

Mirkina, I. (2018). FDI and sanctions: An empirical analysis of short-and long-run effects. European Journal of Political Economy, 54, 198-225. https://doi.org/10.1016/j.ejpoleco.2018.05.008

Niño-Amézquita, J., Dubrovsky, V., Jankurová, A. (2017). Innovations and competitiveness in regional development: a comparison of Latin America, Europe, and China. Czech Journal of Social Sciences, Business and Economics, 6(1), 28-36. https://doi.org/10.24984/ cjssbe.2017.6.1.4

OECD (2016). OECD's Producer Support Estimate and Related Indicators of Agricultural Support, Concepts, Calculations, Interpretation and Use (The PSE Manual), Available at: http://www.oecd.org/tad/agricultural-policies/full\%20text.pdf Accessed 12 May 2019

Pesaran, M. H. (2006). Estimation and inference in large heterogeneous panels with a multifactor error structure. Econometrica, 74(4), 967-1012. https://doi.org/10.1111/j.1468-0262.2006.00692.x

Rosstat (2019). Federal State Statistics Service: Federal Trade Statistics. Available at: http://www.gks.ru/wps/wcm/connect/rosstat_ main/rosstat/ru/statistics/ftrade/ Accessed 14 May 2019

Smutka, L., Spicka, J., Ishchukova, N., \& Selby, R. (2016). Agrarian import ban and its impact on the Russian and European Union agrarian trade performance. Agricultural Economy-Zemedelska Ekonomika, 62(11), 493-506. https://doi.org/10.17221/294/2015AGRICECON

Tireuov, K., Mizanbekova, S., Kalykova, B., Nurmanbekova, G. (2018). Towards food security and sustainable development through enhancing efficiency of grain industry. Enterpreneurship and Sustainability Issues, 6(1), 446-455. http://doi.org/10.9770/ jesi.2018.6.1(27)

Tvaronavičienè, M. (2018). Toward efficient policy making: forecasts of vulnerability to external global threats. Journal of Security and Sustainability Issues, 7(3), 591-600. https://doi.org/10.9770/jssi.2018.7.3(18)

Vorotnikov, I.L., Sukhanova, I.F., Lyavina, M.Y., Glukhova, M.I., Petrov, K.A. (2019). Economic sanctions and import substitution. Entrepreneurship and Sustainability Issues, 6(4), 1872-1883. http://doi.org/10.9770/jesi.2019.6.4(23)

Wegren, S.K., \& Elvestad, C. (2018). Russia's food self-sufficiency and food security: an assessment. Post-Communist Economies, 30(5), 565-587. https://doi.org/10.1080/14631377.2018.1470854

Wegren, S.K., Nikulin, A.M., \& Trotsuk, I. (2017). The Russian Variant of Food Security. Problems of Post-Communism, 64(1-2), 4762. https://doi.org/10.1080/10758216.2016.1163229

Wegren, S.K., Nilssen, F., \& Elvestad, C. (2016). The impact of Russian food security policy on the performance of the food system. Eurasian Geography and Economics, 57(6), 671-699. https://doi.org/10.1080/15387216.2016.1222299

Wengle, S. (2016). The domestic effects of the Russian food embargo. Demokratizatsiya, 24(3), 281-289. 
Short biographical note about the contributors at the end of the article (name, surname, academic title and scientific degree, duties, research interests):

Luboš SMUTKA is Doctor of Economic Sciences and a a Professor at the Department Department of Trade and Finance at the Czech University of Life Sciences in Prague, Czech Republic. Professor Smutka is an author of numerous paper and reports in the journals indexed in Web of Science and Scopus. Research interests: agricultural policy; international trade; regional development; economic growth.

ORCID ID: orcid.org/0000-0001-5385-1333

Mikhail KRIVKO is a PhD student at the Department Department of Trade and Finance at the Czech University of Life Sciences in Prague, Czech Republic.. Research interests: rural development; agricultural market; regional development; econometrics.

Wadim STRIELKOWSKI is a Doctor of Economic Sciences and a Research Associate at the Department Department of Trade and Finance at the Czech University of Life Sciences in Prague, Czech Republic. Research interests: entrepreneurship; small and medium enterprises; rural development; energy conomics; labour economics.

ORCID ID: orcid.org/0000-0001-6113-3841

This work is licensed under the Creative Commons Attribution International License (CC BY). http://creativecommons.org/licenses/by/4.0/ 